November 2009 draft prepared for a special issue of Hydrobiologia dedicated to "Global change and river ecosystems"

\title{
Biogeochemical implications of climate change for tropical rivers and floodplains
}

\author{
Stephen K. Hamilton
}

W.K. Kellogg Biological Station and Department of Zoology, Michigan State University, 3700 E. Gull Lake Drive, Hickory Corners, MI 49060-9516 USA. Email: hamilton@msu.edu. Tel. 269-671-2231, FAX 269-671-2104.

Keywords: Global warming, temperature, wetlands, carbon dioxide, oxygen, biogeochemistry

"This paper has not been submitted elsewhere in identical or similar form, nor will it be during the first three months after its submission to Hydrobiologia." 


\section{Abstract}

Large rivers of the tropics, many of which have extensive floodplains and deltas, are important in the delivery of nutrients and sediments to marine environments, in methane emission to the atmosphere, and in providing ecosystem services associated with their high biological productivity. These ecosystem functions entail biogeochemical processes that will be influenced by climate change. Evidence for recent climate-driven changes in tropical rivers exists but remains equivocal. Model projections suggest substantial future climate-driven changes, but they also underscore the complex interactions that control landscape water balances, river discharges, and biogeochemical processes. The most important changes are likely to involve: 1 ) aquatic thermal regimes, with implications for thermal optima of plants and animals, rates of microbially mediated biogeochemical transformations, density stratification of water bodies, and dissolved oxygen depletion; 2) hydrological regimes of discharge and floodplain inundation, which determine the ecological structure and function of rivers and floodplains and the extent and seasonality of aquatic environments; and 3) freshwater-seawater gradients where rivers meet oceans, affecting the distribution of marine, brackish, and freshwater environments and the biogeochemical processing as river water approaches the coastal zone. In all cases climate change affects biogeochemical processes in concert with other drivers such as deforestation and other land use changes, dams and other hydrological alterations, and water withdrawals. Furthermore, changes in riverine hydrology and biogeochemistry produce potential feedbacks to climate involving biogeochemical processes such as decomposition and methane emission. Future research should seek improved understanding of these changes, and long-term monitoring should be extended to shallow waters of wetlands and floodplains in addition to the larger lakes and rivers that are most studied. 


\section{Introduction}

In the process of conveying water and materials from uplands to the oceans, large tropical rivers and their floodplains are sites of intense biogeochemical activity associated with the passage of river water through highly productive floodplains and estuaries. Rivers and their floodplains provide important ecosystem services, supporting biodiversity, freshwater and marine fisheries, traditional human livelihoods, and productive agricultural land (Junk 1997). Many large tropical rivers have not been regulated by dams (Nillson et al. 2005), and therefore retain seasonally variable hydrological regimes and periodically inundated floodplains, characteristics that exert important influence on aquatic biogeochemical processes and fluxes (Lewis et al. 2000). Extensive seasonal inundation in many tropical floodplains makes them major natural sources of methane emission to the atmosphere (Melack et al. 2004, Denman et al. 2007). Large tropical rivers are important in the delivery of nutrients and sediments to marine environments, and this material influx supports productive estuarine and coastal marine ecosystems (Cotrim da Cunha et al., 2008). Where rivers meet the oceans, deltas and estuaries are important sites of biogeochemical transformations including biological production, sediment retention and nutrient transformation (Bianchi 2007).

This paper reviews literature on whether climate-driven changes are already taking place in tropical ecosystems, how future climate change is expected to affect large tropical rivers and their floodplains, and the potential biogeochemical implications of these effects. Large tropical river systems drain catchments ranging from rainforest to dryland and from relatively pristine to heavily impacted by human activity. In all cases climate change will affect biogeochemical processes in concert with other anthropogenic drivers such as land use change, construction of dams and other river channel alterations, and water withdrawals. Also, changes in catchment vegetation and land use likely will produce potential hydrological feedbacks to climate that remain poorly understood. Evidence reviewed here indicates that climate change potentially is expected to profoundly 
influence the biogeochemical processes that underpin ecosystem functions of large rivers and their floodplains and estuaries, most prominently via hydrological changes in the catchments and rising sea levels at the river mouths, but potentially also via a host of other interactions. Tropical river catchments encompass a broad range of climatic settings, human activity, and geomorphology, and thus the hydrological and biogeochemical implications of climate change will be variable across river systems.

\section{Tropical river hydrology and climatic regimes}

Major tropical river systems and their associated floodplains are described by Welcomme (1985) and include systems with largely natural hydrological regimes, such as the Amazon and Orinoco rivers of South America, as well as systems that have been strongly impacted by hydrological modifications including large dams, such as the Paraná River in South America and the Niger River in Africa. All of these river systems are seasonally variable in discharge and many have extensive floodplains and deltas, although large dams can reduce variability in discharge and inundation. Floodplains fringing large rivers typically include areas flooded by riverine overflow as well as areas subject to inundation from local sources that drains through floodplains into a river system (Mertes 2000, Hamilton 2008a). Large tropical rivers deliver $-35 \%$ of global freshwater discharge to the oceans (Vörösmarty et al. 1997).

Seasonal variation in temperature, precipitation, and river discharge occurs over most of the tropics, and is most marked in the "wet-dry tropics" (tropical latitudes higher than $\sim 10^{\circ}$ ), where climatic seasonality is driven by the shifting latitudinal location of the equatorial trough and the inter-tropical convergence zone (Talling \& Lemoalle 1998). Seasonal variation in temperature and river discharge may or may not be coincident in timing. For example, inundation of much of the Pantanal wetland of Brazil takes place in the warmer months (Hamilton et al. 1996), whereas river flooding in the Okavango Delta in Botswana coincides with the cool season (Ramberg et al., 2006). The Amazon River system drains 
catchments on both sides of the equator with roughly opposite seasonal discharge patterns and as a result the seasonality of discharge and floodplain inundation along the main stem is somewhat attenuated (Hamilton et al. 2002).

The El Niño-Southern Oscillation (ENSO) cycle, which is associated with sea surface temperature anomalies in the tropical Pacific, exerts considerable influence on precipitation patterns in the tropics and subtropics (Foley et al. 2002, Bates et al. 2008). ENSO variability partly explains the interannual variability in river discharges and floods and droughts in regions as distant as southern Africa and Australia. Large tropical rivers with discharges that are particularly influenced by ENSO events include the Nile, Amazon, Congo, Paraná, and Ganges (Khan et al. 2006). The erratic behavior of tropical cyclones also contributes to the interannual variability in the hydrological regimes of tropical rivers in regions where much of the rainfall is associated with cyclonic activity, such as southeast Asia and northern Australia.

Floodplain waters are among the warmest surface waters in tropical regions because they tend to be shallow (and thus they concentrate heat accumulation and track short-term fluctuations in air temperatures) and they lie at low elevations. Water depths can be $>10$ meters in the main channels of the largest rivers, but the mean depth on fringing floodplains is typically much less, and often not deep enough to develop persistent hypolimnetic anoxia, even in the permanent floodplain lakes (e.g., Hamilton \& Lewis 1990, Hamilton et al. 1990). Most discussions of thermal regimes in tropical fresh waters have dealt with large lakes, for which there are many published examples, and often these are deep enough to be seasonally stratified and many of the most studied tropical lakes lie well above sea level (Talling \& Lemoalle 1998).

Shallow and quiescent waters on floodplains or in rivers with little or no flow are more subject to diel temperature fluctuation in response to short-term gains and losses of heat. Diurnal stratification is characteristic of these waters and is a phenomenon subject to change in a warming climate, as discussed later. An 
example of thermal seasonality in relatively shallow waters of tropical rivers and floodplains is presented in Fig. 1, which shows typical seasonal fluctuations in daytime temperatures in waters of the Brazilian Pantanal. Fig. 2 shows a diel cycle of temperature during the late dry-season in a slowly flowing monsoon river of northern Australia.

Similar water temperatures, commonly exceeding $30^{\circ} \mathrm{C}$ but not often approaching $40^{\circ} \mathrm{C}$ during the warm season, have been measured in other shallow tropical waters in the wet-dry tropics. For example, measurements made in a rice field pool of northeastern Thailand $\left(\sim 17.5^{\circ} \mathrm{N}\right.$ latitude) by Heckman (1979) showed frequent maxima above $35^{\circ} \mathrm{C}$. Water temperatures in more equatorial locations usually do not reach such extremes due to attenuation of solar radiation by clouds (Lewis 1987). Also, floodplains where precipitation is more equitably distributed throughout the year tend to have dense vegetation canopies that shade the water. Nonetheless, in shallow and uncanopied water bodies daytime water temperatures can surpass $30^{\circ} \mathrm{C}$, as shown for example in data for an Amazon floodplain lake by Melo \& Huszar (2000), for Orinoco floodplain lakes by Hamilton et al. (1990), and in the Paraguay River by Hamilton et al. (1997). Thus for this review the water temperature range of interest is approximately $15-40{ }^{\circ} \mathrm{C}$, recognizing that maximum temperatures above $\sim 35^{\circ} \mathrm{C}$ are likely only in the shallowest waters.

Water temperatures in lakes and larger rivers are commonly measured although typically published only in summary form, obscuring the minima and maxima that can be important for biogeochemical and ecological processes. Temperatures in shallow waters of wetlands and floodplains are not measured as often, and when done so it is usually for a limited time, serving as ancillary information for studies focused on other topics. Long-term monitoring of water temperatures in a diversity of tropical water bodies, in conjunction with meteorological data collection nearby, would be a wise investment to improve our understanding of the thermal implications of climate change for aquatic ecosystems and could 
readily be done using inexpensive continuous logging systems, provided that rigorous calibration protocols were in place.

\section{Climate change in the tropics: Past trends and future projections}

Current consensus on how climate change is projected to affect tropical regions is drawn mainly from the Intergovernmental Panel on Climate Change (IPCC) Technical Paper on Climate Change and Water (Bates et al. 2008), which is based on the Fourth Assessment Report (IPCC 2007, Kundzewicz et al. 2008), and references cited therein. Additional information was drawn from CCSP (2008).

Temperatures in the tropics are projected to warm $2-4{ }^{\circ} \mathrm{C}$ by 2100 (Meehl et al. 2007). The warming temperatures will extend tropical climates poleward and upward in elevation. Evaporation rates and atmospheric moisture fluxes are often projected to increase significantly as the temperatures rise because the saturation water vapour pressure increases non-linearly with temperature. However, evaporation rates are influenced by complex interacting factors associated with local geography and prevailing climatic conditions, and increases in atmospheric humidity and/or wind can counterbalance the temperature effect and even result in decreased evaporation rates (Hobbins et al. 2004, 2008).

Hydrological fluxes including precipitation, evaporation and runoff will intensify as a result of the increase in atmospheric temperature and moisture and consequent changes in atmospheric circulation. A general tendency in model projections for a warming climate is that presently wet climates become wetter and dry climates become drier, and this appears to hold for the tropics as well as globally (IPCC 2007). Increasing subtropical aridity is also projected, but mainly at the poleward flanks of the subtropics (Cook et al. 2008). 
Timing and volume of river discharges respond strongly to changes in precipitation and are usually somewhat less sensitive to changes in evaporation rates and storage reservoirs (e.g., ground water, soil moisture, artificial reservoirs, and in high-elevation catchments, snow and ice). Thus altered river hydrological regimes are expected to occur particularly as a result of changes in precipitation regimes. However, certain rivers also may change significantly in response to changes in evaporation rates, particularly in dryland catchments where a larger fraction of the precipitation is lost to evaporation (Goudie 2006), as well as in high-elevation catchments such as the Himalayas where seasonal water storage as snow is important (Nijssen et al. 2001).

Many studies have searched for global trends in river discharge, precipitation, and water quality over recent decades, but a clear consensus has yet to emerge. Recent work has pointed to an overall trend of increasing river discharge over the past century (Labat et al. 2004, Gerten et al. 2008), although the quality of the data set underpinning this conclusion has been questioned (Peel \& McMahon 2006, Milliman et al. 2008), and the increase has yet to be rigorously verified. Precipitation also fails to show discernable trends in total amount in the tropics (Bates et al. 2008), although trend detection is difficult in the face of high interannual variability in precipitation, in part related to ENSO variation. While there may have been a global increase in river discharges, evidence so far indicates that trends across the tropics have certainly not been homogeneous (Bates et al. 2008) and are likely to be spatially variable in the future. For example, regional decreases in annual runoff have been noted for parts of West Africa and southern South America (Milly et al. 2005, Li et al. 2007). Recent assessments of trends in water quality also fail to show globally consistent changes that can be attributed to climate change (Bates et al. 2008). This lack of conclusive evidence for global trends is not surprising because hydrological changes associated with a changing global climate are expected to be spatially heterogeneous and difficult to discern from natural variability and catchmentspecific hydrological alterations by human activities. 
Despite the ongoing debates about whether precipitation and river discharges have changed in the recent past, there is good reason to believe that a combination of global climate change and human interferences in land and river hydrology will increasingly alter river hydrological regimes in the future. Specific projections are challenging, however, because river runoff reflects the net result of multiple interacting processes. Several studies have examined the idea that increased runoff could arise from increased plant water use efficiency in response to greater atmospheric $\mathrm{CO}_{2}$ availability, via reduced need for stomatal gas exchange and consequent evapotranspirative water losses (Gedney et al. 2006, Betts et al. 2007). However, other modelling work has suggested that this plant physiological response should be compensated by $\mathrm{CO}_{2}$-stimulated increases in plant biomass, and that in some tropical regions past increases in runoff appear to have been driven largely by changing land use, with climate change of secondary importance (Piao et al. 2007). Another recent modelling study of past discharge records has demonstrated the potential importance of changes in land cover, temperature, and irrigation in addition to precipitation and $\mathrm{CO}_{2}$ (Gerten et al. 2008).

Multi-model ensemble projections extending to time spans of 50-100 years provide the best available indication of where future climatic changes are likely to be most important (Nohara et al. 2006). In general, these model ensembles project that by mid-century mean annual precipitation and runoff will decrease by $10-30 \%$ in some dry subtropical and tropical regions and increase by $10-40 \%$ in some wet tropical regions (Milly et al. 2005, Bates et al. 2008). For example, mean annual runoff is projected to decrease in southern Africa, tropical Mexico, central America and northeast Brazil, to increase in eastern equatorial Africa and the La Plata River catchment in South America, and to change less in much of the Amazon and Orinoco catchments. Regions subject to monsoonal regimes are likely to become wetter, including southern Asia and northern Australia. Evaporation and evapotranspiration may increase with warming temperatures, and as mentioned before this could counteract the effect of increased 
precipitation on runoff, especially in dryland rivers (Dai et al. 2004, Cai \& Cowan 2008). However, climate warming models that project increased evaporation in a warmer world may overemphasize the role of temperature alone as a driver of evaporation (Hobbins et al. 2008).

Despite the uncertainty of model projections, in many tropical rivers the projected changes in discharge over the next 100 years are similar to or greater than the envelope of natural variability over the past 9000 years, a period of substantial variability driven mainly by changes in solar insolation arising from orbital variations (Aerts et al. 2006). The comparative analysis by Aerts et al. suggests that the Ganges, Mekong, Volta, Congo, and Amazon rivers are in this category, whereas the Nile appears less sensitive to future climate change.

One globally consistent projected trend is toward more intense precipitation events (Cook et al. 2008), which has implications for river hydrological regimes and floodplain inundation even if mean annual precipitation and river discharges are unchanged. The frequency and severity of heavy precipitation events are likely to increase in tropical catchments, as are the extent and occurrence of droughts, with both changes projected to take place in some catchments (Bates et al. 2008, Kundzewicz et al. 2008). For rivers in general, studies have documented how precipitation intensity strongly influences rates of soil erosion and sediment transport into rivers, peak discharges that control many fluvial geomorphological processes, and timing and duration of floodplain inundation (Goudie 2006). Tropical rivers would behave similarly in these regards, albeit with the most potential for soil erosion in seasonally dry catchments.

Droughts appear to have become more common in recent years, showing some correspondence with elevated sea surface temperatures in tropical regions, although their attribution to climate change remains uncertain (Bates et al. 2008, cf. Sheffield \& Wood 2008, Marengo et al. 2008). Drier parts of the northern subtropics are particularly likely to experience greater seasonal water limitation (Bates et al. 2008). It is important to recognize that seemingly mild droughts in 
normally humid regions can cause major changes in vegetation and organic carbon stocks, often via increased fire influence (Marengo et al. 2008). For river systems in populated regions with limited water supplies, stronger or more protracted droughts will increase pressure to withdraw river water for consumptive uses or interbasin diversions (Palmer et al. 2008).

Glacier-fed rivers will temporarily increase in discharge then decrease as the glacial ice becomes diminished. Loss of glacial and snowmelt sources will in some cases impact significant tropical rivers and water supplies downstream, as for example in tropical Andean alpine areas (Bradley et al. 2006) and in rivers arising in the Himalayas (WWF 2005). Glacial retreat or disappearance may not greatly affect discharge of the larger South American rivers because most of their water originates from more lowland catchments. However, glaciers across the Himalayas and the Qinghai-Tibet Plateau are important sources of water, particularly during low-discharge seasons, to rivers such as the Yangtze and Yellow in China, the Mekong in Indochina, the Brahmaputra in Bangladesh, and the Ganges in India.

Models indicate that tropical cyclones are likely to become more intense in the future (Bates et al. 2008). It remains unclear whether tropical cyclone activity has increased as a consequence of climate change (Goudie 2006), although there is evidence that tropical cyclones are becoming more severe (Webster et al. 2005). Notably, storm surges associated with coastal storms will increase in impact and area of influence with sea level rise, whether or not the storms become more severe.

Sea level rise is one of the most certain consequences of a warmer climate, but the magnitude and timing are not easily forecast. Projections of sea level rise are being revised in light of the surprisingly accelerated degradation of continental ice sheets, and rises of $40-100 \mathrm{~cm}$ over the next century are now being projected (Horton et al. 2008), substantially greater than the $28-42 \mathrm{~cm}$ estimates of global models evaluated by the IPCC (2007). Even greater rises 
cannot be ruled out because of the difficulty in predicting ice sheet behaviour (Hansen 2007, Steffen et al. 2008, Solomon et al. 2009). In some large river deltas including those of the Mississippi, Nile and Ganges, the effective sea level rise has been considerably exacerbated by land subsidence, which can result from a variety of processes including decreased sediment loads because of upstream impoundments, oxidation of drained organic soils, and localized withdrawals of groundwater, oil or gas (Ericson et al. 2006).

Large-scale changes in terrestrial vegetation may accompany climate change, particularly where droughts and seasonal water limitation increase to the point where forests are replaced by grasslands, and where the impacts of fires increase. Vegetation water use and land cover have consequences for groundwater recharge and runoff (Li et al. 2007, Costa-Cabral et al. 2007), and may also affect soil erosion and sediment transport into rivers. A substantial fraction of forest in the Amazon catchment may be vulnerable to increased water stress and fires during the dry season, even though total annual precipitation is not projected to change greatly (Bates et al. 2008, Barlow and Peres 2008). Deforestation in the eastern Amazon has also been linked to decreased plant water use and increased runoff (Chaves et al. 2008), which in turn explain recent increases in discharge of large rivers (Coe et al. 2009). Extensive deforestation could result in regional decreases in precipitation through this feedback, however, and the net balance of these counteracting changes is likely to vary depending on catchment characteristics (Coe et al. 2009). As discussed above, such changes in vegetation would affect plant water use (evapotranspiration), and the water use efficiency of plants is also affected by increasing $\mathrm{CO}_{2}$ availability. Large-scale changes in vegetation thus represent one of the strongest feedbacks to climate, particularly where changing vegetation produces large changes in carbon sequestration, water use, or radiation balance (i.e., albedo), but these feedbacks are complex and incompletely understood.

\section{Conceptual model of biogeochemical implications of climate change}


A conceptual model illustrates the major ways in which climate change is hypothesized to affect riverine and floodplain biogeochemistry (Fig. 3). For simplicity the main driver of global change is depicted as radiative forcing and the resultant global atmospheric temperature increase. Ecosystem-wide increases in air temperature will result in myriad ecological implications, and some would propagate from the terrestrial catchments through hydrological flow paths to affect streams and rivers, in addition to changing land cover and ecosystem processes on seasonally inundated floodplains. Among the most notable catchment-wide, direct ecological effects of rising temperatures are increased thermal stress for some organisms, a general ecological disequilibrium producing shifts in ecosystem structure including poleward and altitudinal extension of the ranges of some tropical species, and spread of invasive species that exploit new habitats as thermal limitations are reduced. Changes in terrestrial ecosystems are important but beyond the scope of Fig. 3, which focuses on aquatic biogeochemistry.

Based on my review of the literature, I conclude that the most broadly applicable and probably the most important effects of atmospheric temperature increases on tropical rivers and floodplains entail changes in aquatic thermal and hydrological regimes and, in low-lying coastal areas, sea level rise, which will interact with the other drivers. Increased dissolved $\mathrm{CO}_{2}$ in response to higher partial pressures in overlying air is a distinct and possibly significant first-order effect that interacts with higher temperatures to affect mineral weathering and solubility, which in turn control water chemistry at the site of mineral weathering and may affect riverine solute fluxes. Each of these first-order effects and the higher-order effects that follow from them are discussed below.

\section{Changes in thermal regimes}

Temperature exerts pervasive effects on many aspects of ecosystem structure and function including biogeochemical processes. Direct impacts of warmer temperatures operate mainly through thermodynamics and the physiological 
optima of organisms. Thermodynamics drive faster chemical reaction rates at higher temperatures, and many plants and animals increase their growth efficiency (production:biomass ratios) in response to increasing temperature (Talling \& Lemoalle 1998). However, as temperatures climb the point is reached where biotically mediated reactions are subject to biochemical limitations such as enzyme denaturation and loss of membrane functions. Thermal tolerances for organisms are often cited as temperatures at which they no longer function, but their thermal optima are likely well below those tolerances.

The thermal optima of vascular plants, insects and microbes may be of greatest interest in regard to biogeochemical cycles, although biotic changes at all levels of food webs can have significant biogeochemical implications. Thermal optima tend to be narrower for tropical organisms, at least for tropical ectotherms ranging from insects to vertebrates, than they are for equivalent temperate-zone biota, and the thermal response tends to drop sharply from the optimum range to the maximum tolerable temperature (Deutsch et al. 2008). Seasonal minimum temperatures may dictate the ranges of many tropical plants and animals. At high temperatures (e.g., $>30^{\circ} \mathrm{C}$ ), differences in thermal optima affect competitive dynamics among species, and often species diversity begins to drop around 35 ${ }^{\circ} \mathrm{C}$. Hence seemingly modest temperature increases in tropical environments could produce unexpectedly strong reductions or shifts in biotic composition and diversity, with unknown biogeochemical ramifications.

Heterotrophic microbial activity in natural environments tends to increase with increasing temperature, and experimental work with natural wetland soils and sediments supports this generalization over the temperature range of interest here (i.e., $15-40^{\circ} \mathrm{C}$ ). Overall decomposition rates increase with temperature, although the net effect for soil or sediment organic matter pools depends on whether soil moisture and redox status also change, and whether organic inputs change as a result of changes in plant production (Davidson and Janssens 2006). Currently there is not a consensus as to the importance of temperature increases for net ecosystem carbon balances, and most work has focused on 
upland soils and on northern wetland soils including permafrost. In tropical floodplains subject to seasonal inundation and desiccation, a significant increase in temperature is likely to be accompanied by changes in landscape water balance, the seasonality of soil moisture and inundation, and fire regimes, all factors which may have overriding influences on organic matter pools and fluxes compared to changes in rates of microbial metabolism.

Primary production rates of algae tend to increase with temperature in the range of $15-30{ }^{\circ} \mathrm{C}$, but may fall sharply above about $35^{\circ} \mathrm{C}$, while respiration rates continue to increase (Kirk 1994, Talling \& Lemoalle 1998). However, in most tropical waters primary production rates often are more constrained by nutrient limitation than by temperature (Lewis 1987). Vascular plants with leaves above water are more likely to suffer negative impacts of excessive heating, although plant reaction to overheating has been investigated mainly in terrestrial plants (Berry \& Björkman 1980). Grasses with the $C_{4}$ photosynthetic pathway,can be important components of aquatic vegetation in tropical floodplains (e.g., Junk 1997), and are more tolerant of high temperatures than $C_{3}$ plants. Thus increasing temperatures may tip the balance of competition in favour of $\mathrm{C}_{4}$ grasses, which may decrease the nutritional quality of organic matter for consumers, particularly because $\mathrm{C}_{4}$ grasses tend to have lower nitrogen contents (Gibson 2009) and provide little support of aquatic food webs (Hamilton et al. 1992, Clapcott \& Bunn 2003).

Anaerobic microbial processes may be responsive to temperature increases. Denitrification seems to be a more effective sink for nitrate in warmer waters, and may contribute to the tendency for nitrogen limitation of primary production in tropical fresh waters and riverine estuaries (Talling \& Lemoalle 1998, Downing et al. 1999). Methanogenesis and iron reduction are two competing processes of anaerobic decomposition of particular importance in tropical floodplains (Roden \& Wetzel 2002, Weber et al. 2006) Both methanogenesis and iron reduction show temperature optima of $32-41^{\circ} \mathrm{C}$ in anoxic soils from rice paddies (Yao \& Conrad 2000, Fey et al. 2001). Although total methanogenesis increases with 
temperature, there is molecular and isotopic evidence for strong shifts in the phylogenetic composition of methanogenic archaea as temperatures climb above $30^{\circ} \mathrm{C}$ (Fey et al. 2004), and further shifts in methanogen community composition and methanogenic pathways as temperatures climb above $40{ }^{\circ} \mathrm{C}$ (Fey et al. 2001, Wu et al. 2006, Conrad et al. 2009). Bacterial community structure also changes between 35 and $45{ }^{\circ} \mathrm{C}$ (Conrad et al. 2009).

Based on this body of work focused especially on methanogenesis, it appears likely that heterotrophic microbial metabolism, including anaerobic processes of key interest in biogeochemistry, will increase in response to higher temperatures. Most estimates of the $\mathrm{Q}_{10}$ for aquatic respiration, which refers to the relative increase in rate for a $10^{\circ} \mathrm{C}$ increase in temperature within the normal temperature range of the environment and if all else remains unchanged, range between 2 and 3 (Fenchel 2005). Methanogenesis can have a higher $\mathrm{Q}_{10}$ (Roehm 2005). There may be changes in microbial community composition, but functional redundancy may maintain rates of biogeochemical processes. Thermal stress on the upper end of the temperature range is thus more likely to affect animals and higher plants, while microbes and the processes they mediate seem more resilient within the range of water temperatures that might be experienced.

Tropical wetlands are globally important sources of methane emission to the atmosphere (Denman et al. 2007, Bergamaschi et al. 2007), and hence changes in their contribution can be important as a feedback to climate change. Increased emission of methane by tropical wetlands has been projected, mostly ascribed to higher temperatures but also related to increased inundation (Gedney et al. 2004, Shindell et al. 2004). However, it remains uncertain whether higher methane production rates will necessarily increase methane emission rates due to the complexity of interactions among fermentation, methanogenesis, and methane oxidation (Conrad et al. 2009). 
An important class of effects of warmer temperatures on shallow tropical waters may be more indirect, involving density stratification and mixing patterns. Diurnal stratification and variable degrees of nocturnal mixing are typical of quiescent water columns that are less than 4-5 m deep, and can be marked even when the water is $<1 \mathrm{~m}$ deep. The propensity for diurnal stratification to develop is greater at higher temperatures due to the temperature-density behaviour of water, which results in greater stability changes for a given heat flux as temperatures increase (Lewis 1987). A diurnally stratified water column intensifies heat accumulation near the surface and is more likely to result in thermal stress. Increased occurrence and intensity of diurnal stratification enhances the potential for biogeochemical differentiation between surface and bottom waters, which in turn can increase nutrient limitation of surface waters and oxygen depletion of deeper waters. A sequence of days with incomplete nocturnal mixing can result in anoxic waters and lead to fish kills (Talling \& Lemoalle 1998). In tropical lakes seasonal changes in wind regimes also can be important for stratification and mixing patterns (Talling \& Lemoalle 1998), although wind may be less important as an agent of mixing in shallow and often vegetated waters of floodplains than it is in larger lakes.

Consumption of dissolved $\mathrm{O}_{2}$ proceeds faster and the solubility of $\mathrm{O}_{2}$ is lower at warmer temperatures, and these factors combine to make $\mathrm{O}_{2}$ depletion more likely (Lewis 1987), with consequences for aquatic animals, the rates and nature of microbial processes, and biogeochemical cycles of redox-sensitive elements including many trace metals (Hamilton et al. 1997). Mercury methylation and consequent contamination of food webs may increase with temperature as well (Mauro et al. 1999). The net effect of these changes may be altered species compositions of plants and animals, accompanied by accelerated microbial processes and elemental cycling, with uncertain implications for nutrient limitation and aquatic ecosystem productivity in shallow waters. 


\section{Changes in hydrological regimes}

The effects of altered hydrological regimes on biogeochemical processes in rivers and floodplains may well prove to be more marked than the effects of warmer water temperatures because of the overriding importance of seasonal inundation patterns in dictating ecological and biogeochemical features of these ecosystems (Junk 1997, Hamilton 2008b). Changes in hydrological regimes under a warmer climate begin with the landscape water balance, which responds to changes in precipitation regimes in combination with higher evapotranspiration at warmer temperatures (see above discussion). Thus magnitude and timing of upland runoff, river discharge, and floodplain inundation regimes are all subject to change.

Some major implications of altered hydrological regimes are listed in Figure 3, although the importance of several of these depends on the setting, and they are not unique to tropical river systems. In addition to ecological disequilibria produced by changes in discharge and flood regimes, geomorphological disequilibria invoked by changes in runoff and river discharge can result in enhanced sediment fluxes from uplands to rivers and between rivers and their floodplains and coastal zones (Ericson et al. 2006, Walling 2006, Syvitsky et al 2005). Natural sediment fluxes can be important in nutrient supply as well as in maintaining geomorphologically dynamic environments that often support vegetation in early successional stages. However, enhanced sediment and nutrient fluxes due to changing human land use or climate can result in undesirable geomorphic and ecological disequilibria. Day et al. (2008) discuss implications of changes in inputs of freshwater, sediments and nutrients to coastal zones. Changes in the amount of water moving from upland catchments into river systems usually result in changes in dissolved elemental fluxes as well (Neill et al. 2006), particularly for cases where hydrological transport of solutes in soils and groundwater is the limiting factor (e.g., carbonate mineral dissolution: Raymond et al. 2008). 
The vegetation and organic carbon stocks of floodplain ecosystems tend to be sensitive to particularly severe floods or dry periods, which can create new vegetation successional processes (e.g., forest dieback or plant colonisation of emergent sediments). Droughts and fires can rapidly eliminate years of organic matter accumulation in normally saturated soils or sediments, as has recently been documented in Indonesian peatlands (Ballhorn et al. 2009), and may also release methane stored as occluded gas bubbles.

\section{Changes in salinity, tidal influence, and marine storms}

Salinity is a powerful agent of change in ecological and biogeochemical processes, and in coastal zones the boundary between saline and fresh waters usually involves regular or episodic seawater penetration (see below). Inland waters also can become seasonally saline by evaporative concentration, typically accompanied by dramatic shifts in biotic composition and production, sedimentwater exchanges, and nutrient cycling. Salinization via evaporative concentration is particularly common in arid and semi-arid climates but can also occur to some degree in more humid climates where broad shallow pools remain isolated after floodplain inundation (Talling \& Lemoalle 1998). Changes in landscape water balances can change the distribution and timing of salinization of surface waters (Timms 1999, Hamilton et al. 2005). In addition, some dryland regions are prone to secondary soil salinization when land cover changes from woodland to grassland or crops, which alters the soil hydrology such that naturally existing soluble salts are displaced from deeper soils towards the surface (Abrol et al. 1988).

Where large rivers flow into oceans, climate change will have profound implications for biogeochemical processes at the freshwater/seawater interface because gradients of salinity are fundamentally important to ecosystem structure and function (Bianchi 2007). River deltas reflect the balance between fluvial inputs and marine influences including particularly sea-level rise, and modern deltas have formed during the current period of relatively stable sea levels since 
sea-level rise decelerated in the lower Holocene (Ericson et al. 2006). Day et al. (2008) consider three classes of drivers of importance to coastal wetlands in general, all of which apply to tropical systems and are potentially affected by climate change: sea level rise, changes in storm frequency and duration, and changes in freshwater and sediment inputs. These drivers interact to structure the geomorphology and ecology of coastal wetlands, including freshwater portions of river deltas as well as coastal zones in the area of influence of river discharge and sediment loading, which can extend a considerable distance from large river mouths. Tropical river systems include very extensive coastal deltaic wetlands, such as the deltas of the Amazon, Orinoco, and La Plata rivers in South America, the Ganges-Brahmaputra and Irawaddy rivers in Asia, and the Gulf of Carpenteria region in northern Australia.

Estuarine and coastal wetlands and floodplains usually exist across freshwaterseawater interfaces, reflecting a precarious geomorphological and ecological setting developed over several thousand years of relatively stable sea levels. The most certain prediction of how climate change will affect ecosystems across these salinity gradients is via sea level rise, although as noted above the projected timing and magnitude of sea level rise remain a topic of debate. Increased intensity of tropical storms is another relatively confident prediction derived from climate change models. These two drivers interact because storm surges will penetrate further inland with higher sea levels. Effective sea level rise from a combination of climate change and land subsidence results in inundation of coastal wetlands, seawater intrusion into surface and groundwater, and increased vulnerability to storm surges (Ericson et al. 2006). Inland migration of these coastal ecosystems will not always be possible in the face of natural geomorphological barriers as well as anthropogenic land use that is often intense along coasts. The floodplains of the Mary River in northern Australia near Darwin are an example where modest changes in topography allowed salinity intrusion via tidal creeks that dramatically altered coastal freshwater wetlands, killing vast stands of paperbark trees (Melaleuca spp.)(Knighton et al. 1991). 
Changes in river hydrological regimes are a complicating factor that can interact with rising sea levels. The complex and interactive effects of storm surges, discharge variability, and river channel modifications are exemplified by the Mekong River delta (Wassmann et al. 2004). Decreased discharge (especially during low-discharge periods) worsens the impacts of salinity intrusions. Increased river discharge as a result of climate change could help reduce salinity intrusion and may be associated with higher sediment loads that foster vegetation growth (including particularly mangroves) and land accretion, which in turn may counteract the effects of rising sea levels and provide more protection from storms (Day et al. 2008).

Decomposition rates are lower in fresh waters than brackish waters of comparable hydrology (Craft 2007), and any seawater influence can elevate the importance of sulphur biogeochemistry including sulphate reduction. Low-lying coastal land that is most subject to flooding by sea level rise may contain former marine sediments known as acid sulphate soils, and when rewetted such sediments can produce acidic conditions associated with oxidation of sulfide minerals, with negative impacts on freshwater and terrestrial biota (Fitzpatrick and Shand 2008). Sulfur-linked production of acidity and mobilisation of toxic metals such as Al has been documented in tropical catchments of northern Australia where it is associated with freshwater fish kills (Hart \& McKelvie 1986) as well as negative impacts on coastal marine biota where rivers drain into the Great Barrier Reef ecosystem (Powell \& Martins 2004).

Riverine transport of nutrients to the oceans, which is susceptible to alteration with changes in river hydrological regimes and in the ecosystems they drain, affects marine primary production in coastal waters. Nitrogen delivery is particularly important to coastal marine production (Cotrim da Cunha et al., 2008). Phosphorus, silicon and iron fluxes also affect marine primary production, with effects potentially extending far from river mouths (Subramaniam et al. 2008). Also, deoxygenation of coastal waters is promoted by riverine contributions of nutrients to support phytoplankton growth and of detrital organic 
carbon, both of which lead to increased respiratory oxygen demands (Cotrim da Cunha et al., 2008).

\section{Changes in mineral dissolution and precipitation}

Figure 3 includes several specific chemical weathering processes that are directly influenced by temperature and dissolved $\mathrm{CO}_{2}$ and are of interest because of their biogeochemical implications. Dissolution of minerals responds to increased temperature as well as to $\mathrm{pH}$ (White \& Blum 1995), and in most natural waters $\mathrm{pH}$ tends to be inversely proportional to dissolved $\mathrm{CO}_{2}$ because $\mathrm{CO}_{2}$ reacts in water to produce carbonic acid.

Chemical weathering of silicate minerals is of particular interest because it represents a long-term sink for atmospheric $\mathrm{CO}_{2}$, and because it is the source of base cations, alkalinity, and dissolved silicate in river waters. Silicate is of particular interest because its availability affects the growth of diatoms, which are ubiquitous and abundant forms of algae in fresh and marine waters. Tropical rivers account for $\sim 70 \%$ of global silicon fluxes from land to oceans (Jennerjahn et al. 2006). Silicate mineral dissolution increases with temperature and carbonic acid in water that contacts soils and rocks, and thus the concentrations of dissolved silicate as well as base cations and alkalinity transported to surface waters may be expected to increase in a warmer and $\mathrm{CO}_{2}$-enriched climate. However, changes in erosion rates and hydrologic flows through soils and rocks are also likely to be important controls on riverine export of solutes from silicate weathering (Kump et al. 2000, Jennerjahn et al. 2006, Subramanian et al. 2006).

Carbonate mineral weathering is less common in many highly weathered tropical landscapes but is important to riverine chemistry even where only modest amounts of limestone or dolomite exist, strongly affecting the dissolved inorganic carbon and alkalinity concentrations in river waters. In contrast to silicate minerals, carbonate minerals are less soluble at higher temperatures, but more 
soluble with increased dissolved $\mathrm{CO}_{2}$ (Kump et al. 2000), and their solubility is more likely to be transport-limited (i.e., limited by rate of hydrologic flow through soils and ground water reservoirs). Hence the net impacts of interacting increases in temperature and $\mathrm{CO}_{2}$ plus accompanying hydrological changes on carbonate mineral weathering are hard to determine.

Subsequent precipitation of calcium carbonate in lakes and marine environments is subject to similar controls, with aquatic metabolism acting as an important regulator of dissolved $\mathrm{CO}_{2}$ concentrations in productive fresh waters. Secondary carbonate precipitation in surface waters has numerous biogeochemical implications, affecting phosphorus and trace metal cycling (Kelts \& Hsü 1978, Hamilton et al. 2009). Many large tropical river systems in humid climates, including the Amazon, Paraná, and Orinoco rivers, carry waters that are dilute in dissolved ions and highly supersaturated with dissolved $\mathrm{CO}_{2}$ and therefore are not subject to secondary precipitation of calcium carbonate in their freshwater reaches (Kempe 1982, Oliveira et al. in press).

Changes in carbonate dissolution and precipitation impact carbon and other biogeochemical cycles directly, but in addition they affect calcification by molluscs in fresh waters of rivers and floodplains, where these organisms can play pivotal roles as grazers of phytoplankton and attached algae (Strayer et al. 1999). Relatively acidic fresh waters in some tropical floodplains including a number of rivers in the Amazon River system support low species diversity of molluscs, possibly reflecting the difficulty of biogenic calcification in such waters (Dillon 2000, Oliveira et al. in press). In marine environments the acidifying effect of increased $\mathrm{CO}_{2}$ overrides the counteracting effect of increasing temperatures, producing potentially severe implications for calcifying organisms including corals and plankton (Raven 2005). 


\section{Conclusions}

The prospect of anthropogenically-driven global climate change has many potential implications for biogeochemical processes in tropical rivers and floodplains. The most important changes are likely to involve (Fig. 3):

1) Aquatic thermal regimes, with implications for thermal optima of plants and animals, rates of microbially mediated biogeochemical transformations, density stratification of water bodies, and dissolved oxygen depletion;

2) Hydrological regimes of discharge and floodplain inundation, which determine the ecological structure and function of rivers and floodplains and the extent and seasonality of aquatic environments;

3) Freshwater-seawater gradients where rivers meet oceans, affecting the distribution of marine, brackish, and freshwater environments and the biogeochemical processing of river water reaching the coastal zone.

These changes will, however, be affected by complex human interactions and feedbacks which are difficult to forecast. In river systems that experience decreasing or more variable hydrological regimes, water withdrawals are likely to increase, further exacerbating the hydrologic changes (Alcamo et al. 2007, Kundzewicz et al. 2008). Tropical regions predicted to suffer the greatest water stress for human populations include southern Mexico, northeastern Brazil, parts of northern and southern Africa, and India, driven particularly by increased human demands, with climate change a secondary factor that alleviates increased demand in some cases (Alcamo et al. 2007). Important stressors that can act synergistically with climate change include population increases and urbanization. These need to be considered in developing strategies for adaptation to climate change (Palmer et al. 2008).

Future research should strive to improve detection of current trends and projection of future changes in catchment and river hydrology, with greater 
attention to climate feedbacks and human interactions. Limnological research should include sustained monitoring of thermal and mixing regimes not only in large, deep lakes and rivers, but also in the shallow and often ephemeral waters of floodplains and wetlands. Thermal optima and responses of microbes (and the processes they mediate), plants and animals in the upper temperature range (e.g., $30-40{ }^{\circ} \mathrm{C}$ ) is a topic that deserves greater attention as well.

\section{Acknowledgments}

Ralf Conrad, Michael Hobbins, Jeff Shellberg, and Tim Jardine provided advice on specific aspects. Jeff Shellberg provided temperature data for the Mitchell River, Australia. The author was supported during the preparation of this review by a Commonwealth Environmental Research Facilities Fellowship from the Australian government, as well as by the Australian Rivers Institute of Griffith University and the Tropical Rivers and Coastal Knowledge (TRaCK) program. TRaCK receives major funding for its research through the Australian Government's Commonwealth Environment Research Facilities initiative; the Australian Government's Raising National Water Standards Program; Land and Water Australia; and the Queensland Government's Smart State Innovation Fund. 


\section{References}

Abrol, I. P., J. S. P. Yadav \& F. I. Massoud, 1988. Salt-affected soils and their management. FAO Soils Bulletin 39. Food and Agriculture Organisation of the United Nations, Rome. Available at http://www.fao.org/docrep/x5871e/x5871e00.htm

Aerts, J. C. J. H., H. Renssen, P. J. Ward, H. de Moel, E. Odada, L. M. Bouwer \& H. Goosse, 2006. Sensitivity of global river discharges under Holocene and future climatic conditions. Geophysical Research Letters 33, doi 10.1029/2006GL027493.

Alcamo, J., M. Florke \& M. Marker, 2007. Future long-term changes in global water resources driven by socio-economic and climatic changes. Hydrological Sciences Journal - Journal des Sciences Hydrologiques 52: 247-275.

Ballhorn, U., F. Siegert, M. Mason \& S. Liwin, 2009. Derivation of burn scar depths and estimation of carbon emissions with LIDAR in Indonesian peatlands. Proceedings of the National Academy of Sciences USA, published online before print November 25, 2009, doi: 10.1073/pnas.0906457106

Barlow, J. \& C. Peres, 2008. Fire-mediated dieback and compositional cascade in an Amazonian forest. Philosophical Transactions of the Royal Society B - Biological Sciences 363: 1787-1794.

Bergamaschi, P., C. Frankenberg, J. F. Meirink, M. Krol, F. Dentener, T. Wagner, U. Platt, J. O. Kaplan, S. Korner, M. Heimann, E. J. Dlugokencky, $\&$ A. Goede, 2007. Satellite chartography of atmospheric methane from SCIAMACHY on board ENVISAT: 2. Evaluation based on inverse model simulations. Journal of Geophysical Research 112, D02304, doi:10.1029/2006JD007268.

Bates, B. C., Z. W. Kundzewicz, S. Wu and J. P. Palutikof (eds.), 2008. Climate Change and Water. Technical Paper of the Intergovernmental Panel on Climate Change, IPCC Secretariat, Geneva.

Berry, J. \& O. Björkman, 1980. Photosynthetic response and adaptation to temperature in higher plants. Annual Review of Plant Physiology 31: 491543.

Betts, R. A., O. Boucher, M. Collins, M., P. M. Cox, P. D. Falloon, N. Gedney, D. L. Hemming, C. Huntingford, C. D. Jones, D. M. H. Sexton, \& M. Webb, 2007. Projected increase in continental runoff due to plant responses to increasing carbon dioxide. Nature, 448: 1037-1041.

Bianchi, T. S., 2007. Biogeochemistry of estuaries. Oxford University Press. 
Bradley R. S., M. Vuille, H. F. Diaz \& W. Vergara, 2006. Threats to water supplies in the tropical Andes. Science 312:1755-1756.

Cai, W. \& T. Cowan, 2008. Evidence of impacts from rising temperature on inflows to the Murray-Darling Basin., Geophysical Research Letters 35, L07701, doi:10.1029/2008GL033390.

CCSP, 2008. Abrupt Climate Change. A report by the U.S. Climate Change Science Program and the Subcommittee on Global Change Research [Clark, P.U., A.J. Weaver (coordinating lead authors), E. Brook, E.R. Cook, T.L. Delworth, and K. Steffen (chapter lead authors)]. U.S. Geological Survey, Reston, VA, 459 pp.

Chaves, J., C. Neill, H. Elsenbeer, A. Krusche, S. Germer \& S. Gouveia Neto, 2008. Land management impacts on runoff sources in small Amazon watersheds. Hydrological Processes 22: 1766-1775.

Clapcott, J. E. \& S. E. Bunn, 2003. Can $\mathrm{C}_{4}$ plants contribute to the aquatic food webs of subtropical streams? Freshwater Biology 48: 1105-1116.

Coe, M. T., et al. (2009a), The Influence of historical and potential future deforestation on the stream flow of the Amazon River -- Land surface processes and atmospheric feedbacks, Journal of Hydrology, 369, 165174.

Cook, E.R., P.J. Bartlein, N. Diffenbaugh, R. Seager, B.N. Shuman, R.S. Webb, J.W. Williams, and C. Woodhouse, 2008: Hydrological variability and change. In: Abrupt Climate Change. A Report by the U.S. Climate Change Science Program and the Subcommittee on Global Change Research. U.S. Geological Survey, Reston, VA, pp. 143-257.

Conrad, R., M. Close \& M. Noll, 2009. Functional and structural response of the methanogenic microbial community in rice field soil to temperature change. Environmental Microbiology, doi:10.1111/j.14622920.2009.01909.x.

Costa-Cabral, M. C., J. E. Richey, G. Goteti, D. P. Lettenmaier, C. Feldkötter \& A. Snidvongs, 2007. Landscape structure and use, climate, and water movement in the Mekong River basin. Hydrological Processes 22: 17311746.

Cotrim da Cunha, L., E. T. Buitenhuis, C. Le Quéré, X. Giraud \& W. Ludwig, 2008. Potential impact of changes in river nutrient supply on global ocean biogeochemistry. Global Biogeochemical Cycles 21, GB 407, doi: doi:10.1029/2006GB002718.

Craft, C., 2007. Freshwater input structures soil properties, vertical accretion, and nutrient accumulation of Georgia and U.S tidal marshes. Limnology and Oceanography 52: 1220-1230. 
Dai, A., K. E. Trenberth \& T. Qian, 2004. A global dataset of Palmer Drought Severity Index for 1870-2002: Relationship with soil moisture and effects of surface warming. Journal of Hydrometeorology 5: 1117-1130.

Day, J. W., R. R. Christian, D. M. Boesch, A. Yáñez-Arancibia, J. Morris, R. R. Twilley, L. Naylor, L. Schaffner \& C. Stevenson, 2008. Consequences of climate change on the ecogeomorphology of coastal wetlands. Estuaries and Coasts 31: 477-491.

Davidson, E. A. \& I. A. Janssens, 2006. Temperature sensitivity of soil carbon decomposition and feedbacks to climate change. Nature 440: 165-173.

Denman, K. L., G. Brasseur, A. Chidthaisong, P. Ciais, P. M. Cox, R. E. Dickinson, D. Hauglustaine, C. Heinze, E. Holland, D. Jacob, U. Lohmann, S. Ramachandran, P. L. da Silva Dias, S. C. Wofsy and X. Zhang, 2007. Couplings between changes in the climate system and biogeochemistry. In Solomon, S., D. Qin, M. Manning, Z. Chen, M. Marquis, K.B. Averyt, M.Tignor and H.L. Miller (eds.), Climate Change 2007: The Physical Science Basis. Contribution of Working Group I to the Fourth Assessment Report of the Intergovernmental Panel on Climate Change. Cambridge University Press, Cambridge, UK.

Deutsch, C. A., J. J. Tewksbury, R. B. Huey, K. S. Sheldon, C. K. Ghalambor, D. C. Haak \& P. R. Martin, 2008. Impacts of climate warming on terrestrial ectotherms across latitude. Proceedings of the National Academy of Sciences 105: 6668-6672. doi_10.1073_pnas.0709472105.

Dillon, R. T. Jr., 2000. The Ecology of Freshwater Molluscs. Cambridge University Press, Cambridge, UK.

Downing, J. A., M. McClain, R. Twilley, J. M. Melack, J. Elser, N. N. Rabalais, W. M. Lewis, Jr., R. E. Turner, J. Corredor, D. Soto, A. Yañez-Arancibia, J. Kopaska \& R. W. Howarth, 1999. The impact of accelerating land-use change on the $\mathrm{N}$-cycle of tropical aquatic ecosystems: current conditions and projected changes. Biogeochemistry 46: 109-148.

Ericson, J. P., C. J. Vörösmarty, S. L. Dingman, L. G. Ward \& M. Meybeck, 2006. Effective sea-level rise and deltas: Causes of change and human dimension implications. Global and Planetary Change 50: 63-82.

Fenchel, T., 2005. Respiration in aquatic protists. In del Giorgio, P. A. \& P. J. le B. Williams (eds.), Respiration in Aquatic Ecosystems. Oxford University Press, Oxford: 47-56.

Fey, A., K. J. Chin \& R. Conrad, 2001. Thermophilic methanogens in rice field soil. Environmental Microbiology 3: 295-303.

Fey, A., P. Claus \& R. Conrad, 2004. Temporal change of ${ }^{13} \mathrm{C}$-isotope signatures and methanogenic pathways in rice field soil incubated anoxically at different temperatures. Geochimica et Cosmochimica Acta 68: 293-306. 
Fitzpatrick, R. \& P. Shand, 2008. Inland acid sulfate soils: Overview and conceptual models. In Fitzpatrick, R. \& P. Shand (eds.), Inland Acid Sulfate Soil Systems across Australia. CRC LEME Open File Report No. 249 (Thematic Volume), CRC LEME, Perth, Australia: 6-74. Available at http://www.clw.csiro.au/acidsulfatesoils/documents/ass-book/Ch1-InlandASS.pdf

Foley, J. A., A. Botta, M. T. Coe \& M. H. Costa, 2002. El Niño-Southern Oscillation and the climate, ecosystems and rivers of Amazonia. Global Biogeochemical Cycles 16(4): Art. No. 1132.

Gedney, N., P. M. Cox \& C. Huntingford, 2004. Climate feedback from wetland methane emissions, Geophysical Research Letters 31, L20503, doi:10.1029/2004GL020919.

Gedney, N., P. M. Cox, R. A. Betts, O. Boucher, C. Huntingford \& P. A. Stott, 2006. Detection of a direct carbon dioxide effect in continental river runoff records. Nature 439: 835-838, doi:10.1038/nature04504.

Gerten, D., S. Rost, W. Von Bloh \& W. Lucht, 2008. Causes of change in 20th century global river discharge. Geophysical Research Letters 35, L20405, doi:10.1029/2008GL035258.

Gibson, D. J., 2009. Grasses and Grassland Ecology. Oxford University Press.

Goudie, A. S., 2006. Global warming and fluvial geomorphology. Geomorphology 79: 384-394.

Hamilton, S.K. \& W.M. Lewis, Jr. 1990. Basin morphology in relation to chemical and ecological characteristics of lakes on the Orinoco River floodplain, Venezuela. Archiv für Hydrobiologie 119: 393-425.

Hamilton, S.K., S.J. Sippel, W.M. Lewis, Jr., and J.F. Saunders, III. 1990. Zooplankton abundance and evidence for its reduction by macrophyte mats in two Orinoco floodplain lakes. Journal of Plankton Research 12: 345-363.

Hamilton, S. K., W. M. Lewis, Jr. \& S.J. Sippel, 1992. Energy sources for aquatic animals on the Orinoco River floodplain: Evidence from stable isotopes. Oecologia 89: 324-330.

Hamilton, S. K., S. J. Sippel \& J. M. Melack, 1995. Oxygen depletion and carbon dioxide and methane production in waters of the Pantanal wetland of Brazil. Biogeochemistry 30: 115-141.

Hamilton, S.K., S.J. Sippel \& J.M. Melack, 1996. Inundation patterns in the Pantanal wetland of South America determined from passive microwave remote sensing. Archiv für Hydrobiologie 137: 1-23. 
Hamilton, S. K., S. J. Sippel, D. F. Calheiros, and J. M. Melack, 1997. An anoxic event and other biogeochemical effects of the Pantanal wetland on the Paraguay River. Limnology and Oceanography 42: 257-272.

Hamilton, S. K., S. J. Sippel \& J. M. Melack, 2002. Comparison of inundation patterns in South American floodplains. Journal of Geophysical Research 107 (D20): Art. No. 8038. Available in electronic form; doi 10.1029/2000JD000306.

Hamilton, S.K., S.E. Bunn, M. Thoms, and J.C. Marshall. 2005. Persistence of aquatic refugia between flow pulses in a dryland river system (Cooper Creek, Australia). Limnology and Oceanography 50: 743-754.

Hamilton, S. K., 2008a. Flood plains. In G. E. Likens (ed.), Encyclopedia of Inland Waters. Elsevier.

Hamilton, S. K., 2008b. Floodplain wetlands of large river systems. In G. E. Likens (ed.), Encyclopedia of Inland Waters. Elsevier.

Hamilton, S. K., D. A. Bruesewitz, G. P. Horst \& O. Sarnelle, 2009. Biogenic calcite-phosphorus precipitation as a negative feedback to lake eutrophication. Canadian Journal of Fisheries and Aquatic Sciences 66: 321-342.

Hansen, J. E., 2007. Scientific reticence and sea level rise. Environmental Research Letters 2, doi:10.1088/1748-9326/2/2/024002.

Hart, B.T. \& I. D. McKelvie, 1986. Chemical Limnology in Australia. In P. De Decker \& W. D. Williams (eds.), Limnology in Australia. CSIRO, Melbourne \& Dr. W. Junk Publishers, Dordrecht.

Heckman, C. W., 1979. Rice Field Ecology in Northeastern Thailand. In Illies, J. (ed.), Monographiae Biologicae, vol. 34. Dr. W. Junk Publishers, The Hague.

Hobbins, M. T., J. A. Ramírez \& T. C. Brown, 2004. Trends in pan evaporation and actual evapotranspiration across the conterminous U.S.: Paradoxical or complementary? Geophysical Research Letters 31, L13503, doi:10.1029/2004GL019846.

Hobbins, M. T., A. Dai, M. L. Roderick \& G. D. Farquhar, 2008. Revisiting the parameterization of potential evaporation as a driver of long-term water balance trends. Geophysical Research Letters 35, L12403, doi:10.1029/2008GL033840.

Horton, R., C. Herweijer,C. Rosenzweig,J. Liu, V. Gornitz \& A. C. Ruane, 2008. Sea level rise projections for current generation CGCMs based on the semi-empirical method. Geophysical Research Letters 35, L02715, doi:10.1029/2007GL032486. 
IPCC, 2007. Climate Change 2007: Synthesis Report. Contribution of Working Groups I, II and III to the Fourth Assessment Report of the Intergovernmental Panel on Climate Change, Core Writing Team, R.K Pachauri and A. Reisinger (eds.), IPCC, Geneva.

Jennerjahn, T. C., B. A. Knoppers, W. F. L. Souza, G. J. Brunskill, I. L. Silva \& S. Adi, 2006. Factors controlling dissolved silica in tropical rivers. In Ittekkot, V., D. Unger, C. Humborg \& N. Tac An (eds.), The Silicon Cycle: Human Perturbations and Impacts on Aquatic Systems. Island Press, Washington DC: $29-52$.

Junk. W. J. (ed.), 1997. The Central Amazon Floodplain: Ecology of a Pulsing System. Ecological Studies 126, Springer, New York

Kelts, K. \& K. J. Hsü, 1978. Freshwater carbonate sedimentation. In Lerman, A. (ed.), Lakes: Chemistry, Geology, Physics. Springer-Verlag, New York: 292-323.

Kempe, S., 1982. Long-term records of $\mathrm{CO}_{2}$ pressure fluctuations in fresh waters, SCOPE/UNEP Sonderband 52: 91-332.

Khan, S., A. R. Ganguly, S. Bandyopadhyay, S. Saigal, D. J. Erickson III, V. Protopopescu \& G. Ostrouchov, 2006. Nonlinear statistics reveals stronger ties between ENSO and the tropical hydrological cycle, Geophysical Research Letters 33, L24402, doi:10.1029/2006GL027941.

Kirk, J. T. O., 1994. Light and photosynthesis in aquatic ecosystems. $2^{\text {nd }}$ ed. Cambridge Univ. Press. 509 pp.

Knighton, A. D., K. Mills \& C. Woodroffe, 1991. Tidal-creek extension and saltwater intrusion in northern Australia. Geology 19: 831-834.

Kump L. R., S. L. Brantley \& M. A. Arthur, 2000. Chemical weathering, atmospheric $\mathrm{CO}_{2}$, and climate. Annual Reviews of Earth and Planetary Science 28: 611-667.

Kundzewicz, Z. W., L. J. Mata, N. Arnell, P. Döll, P. Kabat, B. Jiménez, K. Miller, T. Oki, Z. Şen \& I. Shiklomanov, 2008. The implications of projected climate change for freshwater resources and their management. Hydrological Sciences-Journal-des Sciences Hydrologiques, 53: 3-10.

Labat, D., Y. Godderis, J. L. Probst \& J. L. Guyot, 2004. Evidence for global runoff increase related to climate warming. Advances in Water Resources 27: 631-642.

Lewis, W. M. Jr., 1987. Tropical limnology. Annual Review of Ecology and Systematics 18: 159-184. 
Lewis, W.M., Jr., S.K. Hamilton, M.A. Lasi, M. Rodríguez, \& J.F. Saunders, III. 2000. Ecological determinism on the Orinoco floodplain. BioScience 50: 681-692.

Li, K. Y., M. T. Coe, N. Ramankutty \& R. De Jong, 2007. Modeling the hydrological impact of land-use change in West Africa. Journal of Hydrology 337: 258-268.

Marengo, J. A., C. A. Nobre, J. Tomasella, M. D. Oyama G. S. de Oliveira, R. de Oliveira, H. Camargo, L. M. Alves, \& I. F. Brown, 2008. The drought of Amazonia in 2005. Journal of Climatology 21: 495-516. doi: 10.1175/2007JCLI1600.1.

Mauro, J. B. N. J. R. D. Guimarães \& R. Melamed, 1999. Mercury methylation in a tropical macrophyte: Influence of abiotic parameters. Applied Organometallic Chemistry 13: 631-636.

Meehl, G. A., T. F. Stocker, W. D. Collins, P. Friedlingstein, A. T. Gaye, J. M. Gregory, A. Kitoh, R. Knutti, J. M. Murphy, A. Noda, S. C. B. Raper, I. G. Watterson, A. J. Weaver \& Z.-C. Zhao, 2007. Global climate projections. In Solomon, S., D. Qin, M. Manning, Z. Chen, M. Marquis, K. B. Averyt, M. Tignor and H. L. Miller (eds.), Climate Change 2007: The Physical Science Basis. Contribution of Working Group I to the Fourth Assessment Report of the Intergovernmental Panel on Climate Change. Cambridge University Press, Cambridge, UK.

Melack, J.M., L.L. Hess, M. Gastil, B.R. Forsberg, S.K. Hamilton, I. B.T. Lima, \& E.M.L.M. Novo, 2004. Regionalization of methane emissions in the Amazon Basin with microwave remote sensing. Global Change Biology 10: $530-544$.

Melo, S. de \& V. L. M. Huszar, 2000. Phytoplankton in an Amazonian flood-plain lake (Lago Batata, Brasil): Diel variation and species strategies. Journal of Plankton Research 22: 63-76.

Mertes, L. A. K., 2000. Inundation hydrology. In Wohl, E. E. (ed.), Inland Flood Hazards: Human, Riparian, and Aquatic Communities. Cambridge University Press, Cambridge, UK: 145-166.

Milliman, J. D., K. L. Farnsworth, P. D. Jones, K. H. Lu \& L. C. Smith, 2008. Climatic and anthropogenic factors affecting river discharge to the global ocean, 1951-2000. Global and Planetary Change 62 (2008) 187-19.

Milly, P. C. D., K. A. Dunne \& V. Vecchia, 2005. Global pattern of trends in streamflow and water availability in a changing climate. Nature 438: $347-$ 350. doi:10.1038/nature04312.

Neill, C., H. Elsenbeer, A. V. Krutsche, J. Lehmann, D. Markewitz \& R. O. Figueiredo, 2006. Hydrological and biogeochemical processes in a changing Amazon: results from small watershed studies and the large- 
scale biosphere-atmosphere experiment. Hydrological Processes 20: 2467-2476.

Nijssen, B., G. M. O'Donnell, A. F. Hamlet \& D. P. Lettenmaier, 2001. Hydrologic sensitivity of global rivers to climate change. Climatic Change 50: 143175.

Nilsson, C., C. A. Reidy, M. Dynesius \& C. Revenga, 2005. Fragmentation and Flow Regulation of the World's Large River Systems. Science 308: 405408. doi 10.1126/science.1107887

Nohara,_D., A. Kitoh, M. Hosaka \& T. Oki, 2006. Impact of climate change on river discharge projected by multimodel eEnsemble. Journal of Hydrometeorology 7: 1076-1089.

Oliveira, M. D., S. K. Hamilton \& and C.M. Jacobi. In press. Forecasting the expansion of the invasive golden mussel Limnoperna fortunei in Brazilian and North American rivers based on its occurrence in the Paraguay River and Pantanal wetland of Brazil. Aquatic Invasions.

Palmer, M. A., C. A. Reidy Liermann, C. Nilsson, M. Flörke, J. Alcamo, P S. Lake $\& \mathrm{~N}$. Bond, 2008. Climate change and the world's river basins: anticipating management options. Frontiers in Ecology and the Environment 6, doi:10.1890/060148.

Peel, M. C. \& T. A. McMahon, 2006. A quality-controlled global runoff data set. Nature 444: E14.

Piao, S., P. Friedlingstein, P. Ciais, N. de Noblet-Ducoudre, D. Labat \& S. Zaehle, 2007. Changes in climate and land use have a larger direct impact than rising $\mathrm{CO}_{2}$ on global river runoff trends. Proceedings of the National Academy of Sciences 104: 15,242-15,247, doi: 10.1073/pnas.0707213104.

Poff, N. L., J. D. Allan, M. B. Bain, J. R. Karr, K. L. Prestegaard, B. D. Richter, R. E. Sparks \& J. C. Stromberg, 1997. The natural flow regime. BioScience 47: 769-784.

Powell, B. \& M. Martens, 2004. A review of acid sulfate soil impacts, actions and policies that impact on water quality in Great Barrier Reef catchments, including a case study on remediation at East Trinity. Marine Pollution Bulletin 51: 149-164. doi:10.1016/j.marpolbul.2004.10.047

Ramberg, L, P. Wolski \& M. Krah, 2006. Water balance and infiltration in a seasonal floodplain in the Okavango Delta, Botswana. Wetlands 26: 677690.

Raven, J. A. 2005. Ocean Acidification Due to Increasing Atmospheric Carbon Dioxide. Policy Document 12/05. The Royal Society, London, UK. 
Raymond, P. A., N.-H. Oh, R. E. Turner \& W. Broussard, 2008.

Anthropogenically enhanced fluxes of water and carbon from the Mississippi River. Nature 451: 449-452. doi: 10.1038/nature06505.

Roden, E. E. \& R. G. Wetzel, 2002. Competition between Fe(III)-reducing and methanogenic bacteria for acetate in iron-rich freshwater sediments. Microbial Ecology 45: 252-258.

Roehm, C. L., 2005. Respiration in wetland ecosystems. In del Giorgio, P. A. \& P. J. le B. Williams (eds.), Respiration in Aquatic Ecosystems. Oxford University Press, Oxford: 83-102.

Sheffield, J. \& E. F. Wood, 2008. Global trends and variability in soil moisture and drought characteristics, 1950-2000, from observation-driven simulations of the terrestrial hydrologic cycle. Journal of Climate 21: 432453.

Shindell, D. T., B. P. Walter \& G. Faluvegi, 2004. Impacts of climate change on methane emissions from wetlands. Geophysical Research Letters 31, L21202, doi:10.1029/2004GL021009.

Solomon, S., G.-K. Plattner, R. Knutti \& P. Friedlingstein, 2009. Irreversible climate change due to carbon dioxide emissions. Proceedings of the National Academy of Sciences 106: 1704-1709.

Steffen, K., P. U. Clark, J. G. Cogley, D. Holland, S. Marshall, E. Rignot \& R. Thomas, 2008. Rapid changes in glaciers and ice sheets and their impacts on sea level. In Abrupt Climate Change. A Report by the U.S. Climate Change Science Program and the Subcommittee on Global Change Research. U.S. Geological Survey, Reston, VA: 60-142.

Strayer, D. L., N. F. Caraco, J. J. Cole, S. Findlay, \& M. L. Pace, 1999. Transformation of freshwater ecosystems by bivalves: A case study of zebra mussels in the Hudson River. Bioscience 49: 19-27.

Subramaniam, A., P. L. Yager, E. J. Carpenter, C. Mahaffey, K. Björkman, S. Cooley, A. B. Kustka, J. P. Montoya, S. A. Sañudo-Wilhelmy, R. Shipe, and D. G. Capone, 2008. Amazon River enhances diazotrophy and carbon sequestration in the tropical North Atlantic Ocean. Proceedings of the National Academy of Sciences 105: 10460-10465.

Subramanian, V., V. Ittekot, D. Unger \& N. Madhavan, 2006. Silicate weathering in south Asian tropical river basins. In Ittekkot, V., D. Unger, C. Humborg \& N. Tac An (eds.), The Silicon Cycle: Human Perturbations and Impacts on Aquatic Systems. Island Press, Washington DC: 3-12.

Syvitsky, J. P. M., C. J. Vörösmarty, A. J. Kettner \& P. Green, 2005. Impact of humans on the flux of terrestrial sediment to the global coastal ocean. Science 308: 376-380. 
Talling, J. F. \& J. Lemoalle. 1998. Ecological dynamics of tropical inland waters. Cambridge Univ. Press. Cambridge, UK.

Timms, B. V. 1999. Local runoff, Paroo floods and water extraction impacts on the wetlands of Currawinya National Park. In Kingsford, R. T. (ed.), A freeflowing river: The ecology of the Paroo River. New South Wales National Parks and Wildlife Service, Huntsville New South Wales (Australia):51-66

Vörösmarty, C. J., K. Sharma, B. Fekete, A. H. Copeland, J. Holden, J. Marble \& J. A. Lough, 1997. The storage and aging of continental runoff in large reservoir systems of the world. Ambio 26: 210-19.

Walling, D. E., 2006. Human impact on land-ocean sediment transfer by the world's rivers. Geomorphology 79: 192-216.

Wassman, R., N. X. Hien, C. T. Hoanh \& T. P. Tuong, 2004. Sea level rise affecting the Vietnamese Mekong Delta: Water elevation in the flood season and implications for rice production. Climatic Change 66: 89-107. doi 10.1023/B:CLIM.0000043144.69736.b7

Weber, K. A., L. A. Achenbach \& J. D. Coates, 2006. Microroganisms pumping iron: Anaerobic microbial iron oxidation and reduction. Nature Reviews Microbiology 4: 752-764. doi:10.1038/nrmicro1490.

Webster, P. J., G. J. Holland, J. A. Curry \& H.-R. Chang, 2005. Changes in tropical cyclone number, duration, and intensity in a warming environmnent. Science 309: 1844-1846.

Welcomme, R. L., 1985. River Fisheries, FAO Fisheries Technical Paper 262, United Nations Food and Agricultural Organisation, Rome.

White A. F. \& A. E. Blum, 1995. Effects of climate on chemical weathering rates in watersheds. Geochimica et Cosmochimica Acta 59: 1729-1747.

Wu, X. L., M. W. Friedrich \& R. Conrad, 2006. Diversity and ubiquity of thermophilic methanogenic archaea in temperate anoxic soils. Environmental Microbiology 8: 394-404.

WWF, 2005. An Overview of Glaciers, Glacier Retreat and Subsequent Impacts in Nepal, India and China. S. C. Rai (coordinator), World Wide Fund for Nature (WWF) Nepal Program. Available at http://assets. panda.org/downloads/himalayaglaciersreport2005.pdf

Yao, H. \& R. Conrad, 2000. Effect of temperature on reduction of iron and production of carbon dioxide and methane in anoxic wetland rice soils. Biology and Fertility of Soils 32: 135-141. 


\section{Figures}

Figure 1. Seasonal fluctuations in daytime temperatures in surface waters of the Brazilian Pantanal, collected by the author at numerous river and floodplain sites over the course of biogeochemical investigations (Hamilton et al. 1995). Most of the waters sampled were $<3 \mathrm{~m}$ and many were $<1 \mathrm{~m}$ deep, and were located between 17-18 ${ }^{\circ} \mathrm{S}$ latitude.

Figure 2. Example of a diel temperature cycle in an open (uncanopied) riffle of a slowly flowing river of northern Australia during the late dry season (Mitchell River, $16.5^{\circ} \mathrm{S}$ latitude, 4-5 Nov 2007).

Figure 3. Conceptual model depicting the major ways in which climate change is hypothesized to affect riverine and floodplain biogeochemistry. First-order effects of the increased atmospheric temperature on aquatic ecosystems are depicted as ovals and higher order effects as diamonds. These effects have ecological and biogeochemical implications that are listed in the boxes. Hydrological regimes encompass the magnitude, timing, duration, frequency, and rate of change of key characteristics including water level, discharge, and extent of inundation (Poff et al. 1997). 


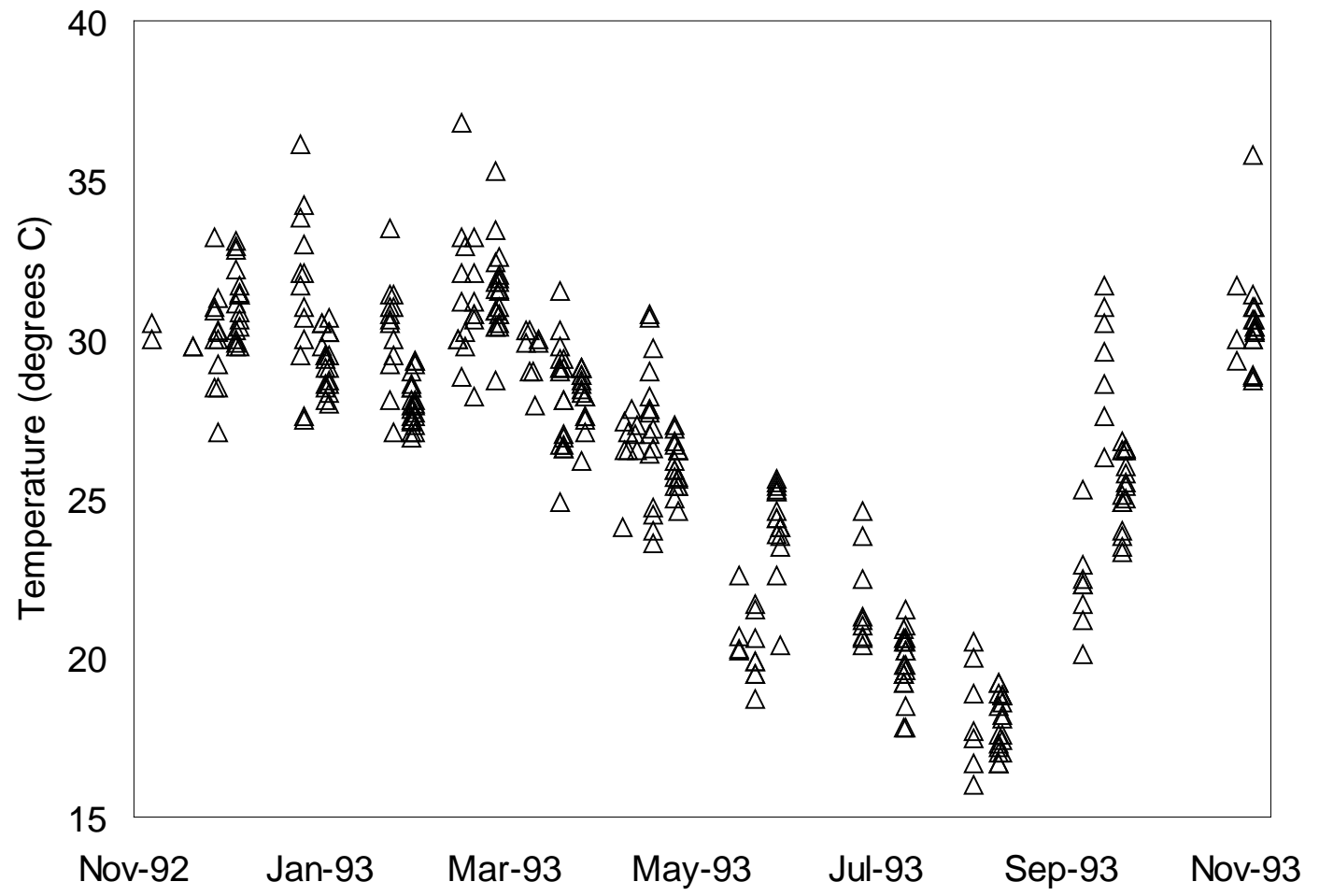

Fig.1 


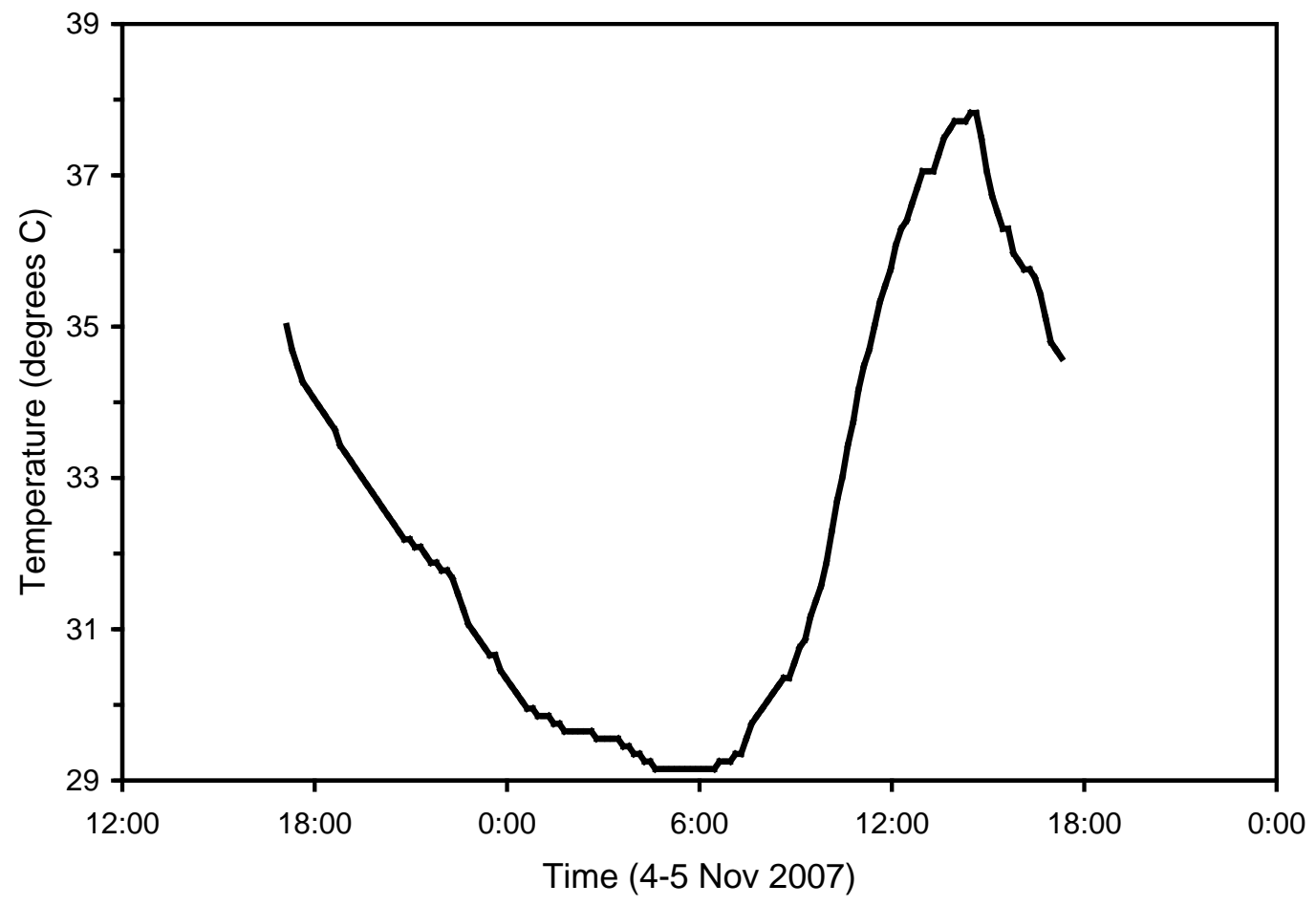

Fig.2. 


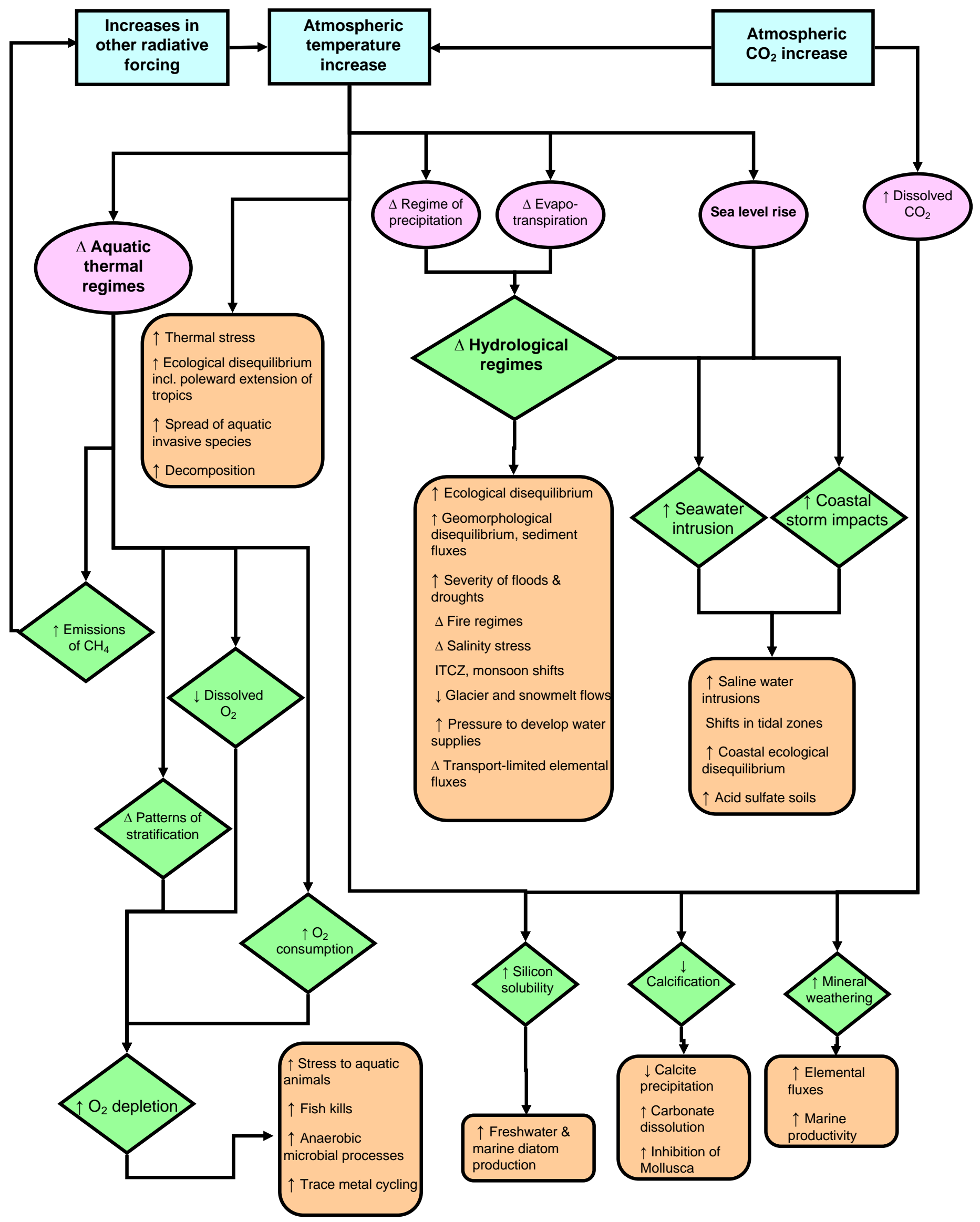

Fig. 3 (colour version for online) 
